\title{
$\begin{array}{ll}\text { Research Square } & \text { Preprints are preliminary reports that have not undergone peer review. } \\ \text { They should not be considered conclusive, used to inform clinical practice, } \\ \text { or referenced by the media as validated information. }\end{array}$
}

\section{Simultaneous determination of C4-C9 alkylphenols and bisphenol A in environmental water at the Yellow River Estuary Area in China by gas chromatography-mass spectrometry}

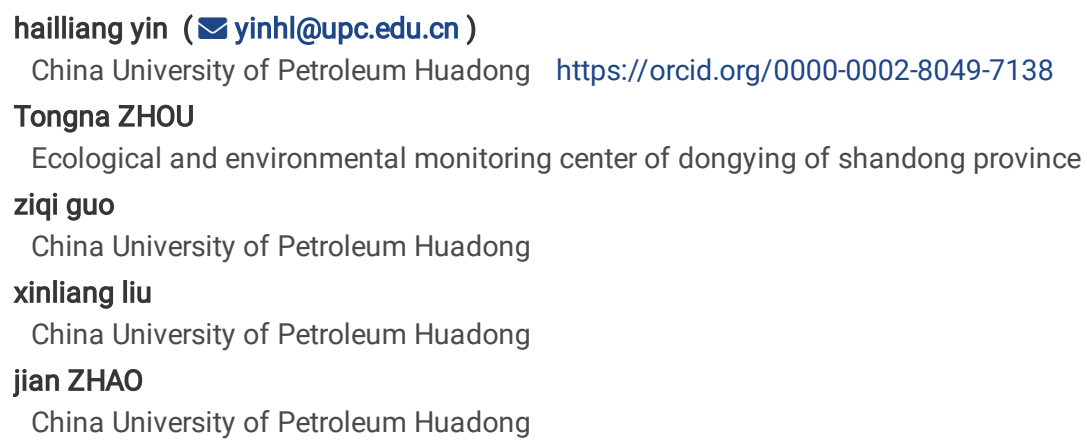

\section{Research Article}

Keywords: Environmental water, C4-C9 alkylphenol, Bisphenol A, Gas chromatography-mass spectrometry, Liquid-liquid extraction, Yellow River Estuary area

Posted Date: March 22nd, 2021

DOI: https://doi.org/10.21203/rs.3.rs-195989/v1

License: (c) (i) This work is licensed under a Creative Commons Attribution 4.0 International License. Read Full License 


\section{Abstract}

A liquid-liquid extraction combined with derivatization and gas chromatography-mass spectrometry (GC-MS) method was developed for the rapid determination of C4-C9 alkylphenols (4-tert-butylphenol, 4-n-butylphenol, 4-n-pentylphenol, 4-n-hexylphenol, 4-n-heptylphenol, 4-n-octylphenol, 4-tertoctylphenol, 4-n-nonylphenol and 4-nonylphenol) and bisphenol A in the environmental water. The extraction solvent, extraction time, solvent volume, acidity, salt content and the distillation degree were optimized. After drying and dehydration, the extract was derivatized, detected by GC-MS and quantified by internal standard method. After the dehydration, the extract was derivatized with BSTFA, detected by GC-MS and quantified by internal standard method. The results showed that the relative standard deviations of the relative response factors of the target compounds were less than $20 \%$, the method detection limits were $0.002 \mu \mathrm{g} / \mathrm{L} \otimes 0.006 \mu \mathrm{g} / \mathrm{L}$, the relative standard deviations of the three spiked levels were $0.67 \% \otimes 13.7 \%$, and the average recoveries of the actual water samples were $68.0 \% \otimes 122 \%$. The method precision and accuracy were good. The method is simple, rapid, accurate, stable and reliable, which is suitable for the detection of target in water. The contents of C4-C9 alkylphenols and bisphenol A in groundwater, surface water, sewage, waste water and sea water samples in Dongying City located at the Yellow River Estuary were determined by this method. The results showed that the contents of 4-nonylphenol and bisphenol $\mathrm{A}$ in these samples were lower than the home and abroad requirements.

\section{Introduction}

As the typical environmental endocrine disruptors, alkylphenols and bisphenol A have been the focus of attention (Wen et al. 2020; Abu-Alsoud and Bottaro 2021; Liu and Zhao 2020; Murray et al. 2017). There is no domestic standard method to monitor the alkylphenols and bisphenol A in water in China. ASTM, ISO and the Japanese government have developed the corresponding monitoring standard methods (ISO 18857-2 2009; ASTM D7065 2011; ASTM D7574 2009; JIS K 0450-10-10 2006). However, these above monitoring methods were developed early and the research objects are single, which are limited to one or several compounds of 4-tert-octylphenol, nonylphenol and bisphenol A. This is related to the early people's understanding of the use of alkylphenols. The plastic industry developed early, and the nonylphenol and octylphenol were the most widely used in the plastic industry. As a result, the proportion of nonylphenol and octylphenol in the environmental water was high, and the other alkylphenols were not detected or the detection value was very low, which did not attract people's attention. There are many detection methods of alkylphenols and bisphenol A in water, among which the liquid-liquid extraction combined GC-MS method is a more studied method, but the research objects are also concentrated on one or several compounds of 4-tert-octylphenol, nonylphenol and bisphenol A (Selvaraj et al. 2014; Shen et al. 2015; Santhi et al. 2012; Dong et al. 2015; Wang et al. 2013; Martinez and Peñuela 2013). However, with the development of new plastics and liquid crystal products, many new C4-C9 alkylphenols have been widely used. The 4-tert-butylphenol is an important raw material for the production of p-tert-butylphenol formaldehyde resin. The 4-n-pentylphenol is an effective component of disinfectant, food preservative and deodorant. The 4-n-butylphenol, 4-n-hexylphenol and 4-n-heptylphenol are often used as liquid crystal raw materials and intermediates. The wide application of C4-C9 alkylphenols leads to the continuous entry of these new alkylphenols into the environmental water. These C4-C9 alkylphenols are also the endocrine disruptors, which can also affect the performance of human endocrine system. In 1998, the Ministry of environment of Japan listed 4-pentyl phenol and other alkyl phenols as the endocrine disruptors (Ministry of the Environment of Japan 1998). However, there is no standard method for the monitoring of these C4-C9 alkylphenol and bisphenol A in water in China, and there is no standard method developed by the authoritative institutions abroad.

The alkylphenol is a combination of phenol and alkyl chain. Due to the different length of alkyl chain, the physical and chemical properties of these C4C9 alkylphenols are different, such as nonpolarity, adsorption capacity on the material surface and partition coefficient between aqueous phase and organic phase. The greater the difference of alkyl chain length, the greater the difference of these properties. The quantitative determination of these C4C9 alkylphenols and bisphenol A in groundwater, surface water, sewage and wastewater, seawater and other actual water samples is an analytical technique for trace or ultra trace mixed components in complex matrix, which is difficult to extract, enrich, separate and detect. Liquid-liquid extraction has the advantages of good separation effect, simple operation and high repeatability, which is the most widely used organic matter extraction and enrichment technology (Wang et al. 2020; Deng et al. 2018). GC-MS is the most advanced and reliable detection technology (Subuhi et al. 2020; Azzouz et al. 2020). After the derivatization, the polarity and boiling point of these alkylphenols and bisphenol A decreased, the volatility and stability increased, the anti-interference ability increased, and the samples could be stored for a long time for retest (Liu et al. 2019; Tan et al. 2019).

In this study, a liquid-liquid extraction combined with derivatization and GC-MS method with low detection limit, high recovery, good reproducibility and rapid analysis was established. Nine C4-C9 alkylphenols (4-tert-butyl phenol, 4-n-butyl phenol, 4-n-pentyl phenol, 4-hexyl phenol, 4-heptyl phenol, 4-octyl phenol, 4-tert-octyl phenol, 4-nonylphenol and 4-nonylphenol) and bisphenol A in water were analyzed. The accurate concentrations of target substances in groundwater, surface water, sewage, waste water and sea water were determined.

\section{Materials And Methods}

\subsection{Materials and reagents}

The standard solutions of C4-C9 alkylphenols and bisphenol A (including 4-tert-butyl phenol, 4-n-butyl phenol, 4-n-pentyl phenol, 4-n-hexyl phenol, 4-nheptyl phenol, 4-n-octyl phenol, 4-tert-octyl phenol, 4-n-nonylphenol, 4-nonylphenol and bisphenol A, with the concentration of $1000 \mu \mathrm{g} / \mathrm{ml}$ ), deuterated bisphenol A- $d_{16}$ standard solution $(1000 \mu \mathrm{g} / \mathrm{ml})$, deuterated naphthalene- $\mathrm{d}_{8}$ standard solution $(200 \mu \mathrm{g} / \mathrm{ml})$, deuterated phenanthrene- $\mathrm{d}_{10}$ standard solution $(500 \mu \mathrm{g} / \mathrm{ml})$, and deuterated pyrene- $\mathrm{d}_{10}$ standard solution $(500 \mu \mathrm{g} / \mathrm{ml})$, were purchased from Drehrenstorfer, Germany. Dichloromethane, acetone and $n$-hexane are pesticide residues, purchased from Merda company of USA. The derivatization reagent BSTFA (containing 1\% TMCs) was purchased 
from Drehrenstorfer, Germany. Hydrochloric acid, sodium chloride and anhydrous sodium sulfate are of high grade purity purchased from Sinopharm group of China. Sodium chloride and anhydrous sodium sulfate are roasted at $450{ }^{\circ} \mathrm{C}$.

Alkylphenols and bisphenol A working solution $(1 \mu \mathrm{g} / \mathrm{ml})$, substitute solution $\left(1 \mu \mathrm{g} / \mathrm{ml}\right.$ of deuterated bisphenol A- $\left.\mathrm{d}_{16}\right)$, and internal standard $(1 \mu \mathrm{g} / \mathrm{ml}$ of deuterated naphthalene- $\mathrm{d}_{8}$, deuterated phenanthrene- $\mathrm{d}_{10}$, and deuterated pyrene- $\mathrm{d}_{10}$, respectively) were diluted from the corresponding standard solutions with acetone.

\subsection{Instruments and equipment}

Agilent 7890B gas chromatograph, Agilent 5977B mass spectrometer, Heidolph rotary evaporator.

\subsection{Solution preparation and standard curve}

Water treatment steps: Measured $500 \mathrm{ml}$ water sample into the separating funnel, added $100 \mu \mathrm{l}$ substitute working solution and mixed well. Then added $10 \mathrm{~g}$ sodium chloride, shaked to complete dissolution, added $30 \mathrm{ml}$ dichloromethane, shaked violently for 10 min, standed for 5-10 min, separated layers, collected organic phase, extracted again for 1-2 times, combined organic phase and dehydrated with anhydrous sodium sulfate, and concentrated organic phase to $0.5 \mathrm{ml}$. Transfered the concentrated sample to a $1 \mathrm{ml}$ volumetric flask, washed the concentrated flask with a small amount of dichloromethane, and combined the washing solution into the volumetric flask. Added $100 \mu$ of internal standard working solution and $100 \mu$ l of derivatization reagent in turn, and diluted to $1 \mathrm{ml}$ with dichloromethane. The samples were obtained by derivatization at room temperature for $1 \mathrm{~h}$.

Standard curve preparation: Added $100 \mu$ internal standard working solution and $100 \mu$ l derivatization reagent respectively, and used dichloromethane to make volume to $1 \mathrm{ml}$. The low concentration calibration series are $0 \mu \mathrm{g} / \mathrm{L}, 5.0 \mu \mathrm{g} / \mathrm{L}, 10.0 \mu \mathrm{g} / \mathrm{L}, 20.0 \mu \mathrm{g} / \mathrm{L}, 40.0 \mu \mathrm{g} / \mathrm{L}, 60.0 \mu \mathrm{g} / \mathrm{L}$ and $80.0 \mu \mathrm{g} / \mathrm{L}, \mathrm{while}$ the high concentration calibration series are $60.0 \mu \mathrm{g} / \mathrm{L}, 100 \mu \mathrm{g} / \mathrm{L}, 200 \mu \mathrm{g} / \mathrm{L}, 500 \mu \mathrm{g} / \mathrm{L}, 1000 \mu \mathrm{g} / \mathrm{L}$ and $2000 \mu \mathrm{g} / \mathrm{L}$. After derivatization at room temperature for $1 \mathrm{~h}$, the target compounds were determined from low concentration to high concentration according to the chromatographic reference conditions. The retention time and quantitative ion response values of the standard series of target compounds and corresponding internal standards were recorded. The average relative response factor was used to draw the calibration curve, and the relative standard deviation (RSD) of the relative response factor (RRF) of the standard series of target compounds should not be more than $20 \%$.

\subsection{Actual water sample collection}

According to the relevant environmental protection standards (HJ 91.1 2019; HJ/T 164 2020; HJ/T 493 2009), the sewage, river water, the drainage of wastewater treatment plant and Bohai Sea water were collected in Dongying City. The hydrochloric acid solution was added to adjust the pH of the water sample to be less than or equal to 2 . The water sample should be filled with the sample bottle and sealed. It should be stored under $4{ }^{\circ} \mathrm{C}$ in dark and refrigerated. The extraction and derivation should be completed within 10 days, and the analysis should be completed within 5 days after the extraction.

\subsection{Establishment of analytical method}

(1) Gas chromatographic conditions

Injection port temperature: $300^{\circ} \mathrm{C}$, no split injection. He gas pressure: $40 \mathrm{kPa}$ for $5 \mathrm{~min}, 2 \mathrm{kPa} / \mathrm{min}$ to $70 \mathrm{kPa}, 5 \mathrm{~min}$; column temperature: $50{ }^{\circ} \mathrm{C}, 2 \mathrm{~min}$, $20^{\circ} \mathrm{C} / \mathrm{min}$ to $100{ }^{\circ} \mathrm{C}, 10^{\circ} \mathrm{C} / \mathrm{min}$ to $200{ }^{\circ} \mathrm{C}, 20^{\circ} \mathrm{C} / \mathrm{min}$ to $300{ }^{\circ} \mathrm{C}, 5 \mathrm{~min}$; injection volume: $1 \mu$ l. The chromatographic column was hp-5ms capillary column, $30 \mathrm{~m}$ long, $0.25 \mathrm{~mm}$ inner diameter and $0.25 \mu \mathrm{m}$ film thickness.

(2) Mass spectrometry conditions

Transmission line temperature: $280^{\circ} \mathrm{C}$. Quadrupole temperature: $150{ }^{\circ} \mathrm{C}$. Ion source temperature: $230{ }^{\circ} \mathrm{C}$. Electron energy of ion source: 70 ev. Mass range: 35-400 amu. Data acquisition mode: SIM. The quantitative and qualitative ions are shown in Table 1.

Table 1 Quantitative ion and qualitative ion of target compounds 


\begin{tabular}{|c|c|c|c|c|}
\hline Compound Name & CAS number & Quantitative ion & Qualitative ion & Note \\
\hline deuterated naphthalene- $\mathrm{d}_{8} \otimes I S 1 \rrbracket$ & $1146-65-2$ & 136 & - & - \\
\hline 4-tert-butyl phenol & $98-54-4$ & 207 & 222 & IS 1 \\
\hline 4-n-butyl phenol & $1638-22-8$ & 179 & 222 & IS 1 \\
\hline 4-n-pentyl phenol & $14938-35-3$ & 179 & 236 & IS 1 \\
\hline 4-n-hexyl phenol & $2446-69-7$ & 179 & 250 & IS 1 \\
\hline 4-tert-octyl phenol & $140-66-9$ & 207 & 278 & IS 1 \\
\hline 4-n-heptyl phenol & $1987-50-4$ & 179 & 264 & IS 2 \\
\hline 4-nonylphenol & $84852-15-3$ & 207 & $221 \rrbracket 193$ & IS 2 \\
\hline deuterated phenanthrene- $\mathrm{d}_{10} \mathbb{\nabla S} 2 \nabla$ & $1517-22-2$ & 188 & - & - \\
\hline 4-n-octyl phenol & $1806-26-4$ & 179 & 278 & IS 2 \\
\hline 4-n-nonylphenol & $104-40-5$ & 179 & 292 & IS 2 \\
\hline deuterated pyrene- $\mathrm{d}_{10}$ 『IS 3 ه & $1718-52-1$ & 212 & - & - \\
\hline deuterated bisphenol A-d ${ }_{16} \varangle$ Surrogate $\mathbb{}$ & $96210-87-6$ & 368 & 386 & IS 3 \\
\hline bisphenol A & $80-05-7$ & 357 & 372 & IS 3 \\
\hline
\end{tabular}

\section{Results And Discussion}

\subsection{Influence of extraction solvent}

$500 \mathrm{ml}$ of laboratory water was added into the separating funnel, and then alkylphenol and bisphenol A working solution were added to make the concentration of target substance in the water sample $0.20 \mu \mathrm{g} / \mathrm{L}$. The effects of different extraction solvents on the recovery of target compounds are shown in Table 2. According to the data in the table, dichloromethane has the best extraction effect.

Table 2 Average extraction efficiency of C4-C9 alkylphenols and bisphenol A for different extraction solvents

\begin{tabular}{|c|c|c|c|c|c|c|c|c|c|c|}
\hline $\begin{array}{l}\text { Extraction } \\
\text { solvent }\end{array}$ & $\begin{array}{l}\text { Recovery } \\
\text { rate \% }\end{array}$ & & & & & & & & & \\
\hline $\begin{array}{l}\text { 4-tert-butyl } \\
\text { phenol }\end{array}$ & $\begin{array}{l}\text { 4-n-butyl } \\
\text { phenol }\end{array}$ & $\begin{array}{l}\text { 4-n-pentyl } \\
\text { phenol }\end{array}$ & $\begin{array}{l}\text { 4-n-hexyl } \\
\text { phenol }\end{array}$ & $\begin{array}{l}\text { 4-tert- } \\
\text { octyl } \\
\text { phenol }\end{array}$ & $\begin{array}{l}\text { 4-n-heptyl } \\
\text { phenol }\end{array}$ & $\begin{array}{l}\text { 4- } \\
\text { nonylphenol }\end{array}$ & $\begin{array}{l}\text { 4-n-octyl } \\
\text { phenol }\end{array}$ & $\begin{array}{l}\text { 4-n- } \\
\text { nonylphenol }\end{array}$ & $\begin{array}{l}\text { bisphenol } \\
\mathrm{A}\end{array}$ & \\
\hline Dichloromethane & 104 & 101 & 115 & 101 & 98.7 & 110 & 95.4 & 109 & 120 & 98.8 \\
\hline Hexane & 118 & 13.5 & 83. & 94.1 & 108 & 97.6 & 96.5 & 107 & 87.5 & 106 \\
\hline Ethyl acetate & 91.2 & 84.2 & 83.7 & 65.8 & 72.1 & 80.6 & 65.4 & 82.9 & 66.5 & 76.2 \\
\hline Toluene & 65.3 & 88.9 & 65.0 & 78.5 & 72.0 & 83.6 & 79.4 & 88.1 & 75.4 & 55.1 \\
\hline
\end{tabular}

\subsection{Influence of extraction times}

The effects of different extraction times of dichloromethane on the recovery of target compounds are shown in Table 3 . It can be seen from the table that C4-C9 alkylphenols can be extracted completely after one extraction, and bisphenol A can be extracted mainly after two extraction. When dichloromethane is selected as the extraction solvent, the second extraction can meet the requirements.

Table 3 Average extraction efficiency of C4-C9 alkylphenols and bisphenol A for different extraction times 


\begin{tabular}{|c|c|c|c|c|c|c|c|c|c|c|c|}
\hline $\begin{array}{l}\text { Extraction } \\
\text { times }\end{array}$ & $\begin{array}{l}\text { Recovery } \\
\text { rate \% }\end{array}$ & & & & & & & & & & \\
\hline $\begin{array}{l}\text { 4-tert-butyl } \\
\text { phenol }\end{array}$ & $\begin{array}{l}\text { 4-n-butyl } \\
\text { phenol }\end{array}$ & $\begin{array}{l}\text { 4-n- } \\
\text { pentyl } \\
\text { phenol }\end{array}$ & $\begin{array}{l}\text { 4-n- } \\
\text { hexyl } \\
\text { phenol }\end{array}$ & $\begin{array}{l}\text { 4-tert- } \\
\text { octyl } \\
\text { phenol }\end{array}$ & $\begin{array}{l}\text { 4-n- } \\
\text { heptyl } \\
\text { phenol }\end{array}$ & $\begin{array}{l}\text { 4- } \\
\text { nonylphenol }\end{array}$ & $\begin{array}{l}\text { 4-n- } \\
\text { octyl } \\
\text { phenol }\end{array}$ & $\begin{array}{l}\text { 4-n- } \\
\text { nonylphenol }\end{array}$ & $\begin{array}{l}\text { bisphenol } \\
\mathrm{A}\end{array}$ & Surrogate & \\
\hline 1 & 97.8 & 102 & 113 & 109 & 119 & 117 & 96.9 & 117 & 103 & 76.3 & 62.6 \\
\hline 2 & 1.9 & 2.0 & n.d. & n.d. & n.d. & n.d. & n.d. & n.d. & 1.0 & 24.9 & 27.4 \\
\hline 3 & n.d. & n.d. & n.d. & n.d. & n.d. & n.d. & n.d. & n.d. & n.d. & 4.6 & 5.2 \\
\hline 4 & n.d. & n.d. & n.d. & n.d. & n.d. & n.d. & n.d. & n.d. & n.d. & n.d. & n.d. \\
\hline
\end{tabular}

\subsection{Influence of extraction time}

The influence of different extraction time on the recovery rate of target compounds is shown in Table 4. It can be seen that the extraction time has a slight effect on the extraction efficiency. With the extension of the extraction time, the recovery rate of the target substance increases slightly. It can be seen from the table that the extraction time of 5 minutes is enough to fully recover the target substance in the water sample.

Table 4 Average extraction efficiency of C4-C9 alkylphenols and bisphenol A for different extraction time

\begin{tabular}{|c|c|c|c|c|c|c|c|c|c|c|c|}
\hline $\begin{array}{l}\text { Extraction } \\
\text { time } ₫ \min \rrbracket\end{array}$ & $\begin{array}{l}\text { Recovery } \\
\text { rate \% }\end{array}$ & & & & & & & & & & \\
\hline $\begin{array}{l}\text { 4-tert-butyl } \\
\text { phenol }\end{array}$ & $\begin{array}{l}\text { 4-n-butyl } \\
\text { phenol }\end{array}$ & $\begin{array}{l}\text { 4-n- } \\
\text { pentyl } \\
\text { phenol }\end{array}$ & $\begin{array}{l}\text { 4-n- } \\
\text { hexyl } \\
\text { phenol }\end{array}$ & $\begin{array}{l}\text { 4-tert- } \\
\text { octyl } \\
\text { phenol }\end{array}$ & $\begin{array}{l}\text { 4-n- } \\
\text { heptyl } \\
\text { phenol }\end{array}$ & $\begin{array}{l}\text { 4- } \\
\text { nonylphenol }\end{array}$ & $\begin{array}{l}4-n- \\
\text { octyl } \\
\text { phenol }\end{array}$ & $\begin{array}{l}\text { 4-n- } \\
\text { nonylphenol }\end{array}$ & $\begin{array}{l}\text { bisphenol } \\
\text { A }\end{array}$ & Surrogate & \\
\hline 5 & 98.9 & 101 & 109 & 101 & 118 & 112 & 95.6 & 115 & 106 & 98.7 & 91.0 \\
\hline 10 & 99.7 & 104 & 113 & 109 & 119 & 117 & 96.9 & 117 & 104 & 101 & 90.0 \\
\hline 15 & 104 & 109 & 118 & 117 & 122 & 127 & 98.1 & 123 & 106 & 101 & 92.3 \\
\hline
\end{tabular}

\subsection{Influence of acidity in water}

The effect of acidity in water on the recovery rate of target compounds is shown in Table 5. It can be seen from the table that when the $\mathrm{pH}$ value is higher than 6, the recoveries of 4-nonylphenol and 4-n-octyl phenol decrease, but the recoveries of other target compounds are not affected. Considering that acidic conditions are conducive to inhibiting bacteria in water and preventing bacteria from consuming alkylphenol organics, the pH value of water sample is usually less than 2 .

Table 5 Average extraction efficiency of C4-C9 alkylphenols and bisphenol A for different $\mathrm{pH}$ value

\begin{tabular}{|lllllll|}
\hline $\mathrm{pH} \mathbf{}$ & $<1$ & $1-2$ & $2-3$ & $3-4$ & $4-5$ & $6-7$ \\
\hline 4-tert-butyl phenol & 107 & 98.6 & 107 & 102 & 99.0 & 100 \\
\hline 4-n-butyl phenol & 110 & 99 & 104 & 101 & 99.4 & 96.8 \\
\hline 4-n-pentyl phenol & 117 & 111 & 113 & 110 & 109 & 106 \\
\hline 4-n-hexyl phenol & 117 & 109 & 112 & 108 & 106 & 102 \\
\hline 4-tert-octyl phenol & 122 & 106 & 115 & 110 & 109 & 110 \\
\hline 4-n-heptyl phenol & 125 & 115 & 120 & 114 & 113 & 105 \\
\hline 4-nonylphenol & 105 & 97.3 & 105 & 101 & 97.4 & 91.3 \\
\hline 4-n-octyl phenol & 116 & 106 & 112 & 107 & 107 & 97.7 \\
\hline 4-n-nonylphenol & 121 & 110 & 121 & 115 & 120 & 108 \\
\hline bisphenol A & 110 & 115 & 116 & 108 & 114 & 113 \\
\hline Surrogate & 117 & 110 & 121 & 115 & 114 & 113 \\
\hline
\end{tabular}

\subsection{Influence of extraction solvent volume}

The effects of different extraction solvent volumes on the recovery of target compounds are shown in Table 6 . It can be seen from the table that $20 \mathrm{ml}$ of dichloromethane can meet the extraction requirements.

Table 6 Average extraction efficiency of C4-C9 alkylphenols and bisphenol A for different extraction solvent volume 


\begin{tabular}{|c|c|c|c|c|c|c|c|c|c|c|c|}
\hline $\begin{array}{l}\text { Extraction } \\
\text { solvent } \\
\text { volume } \varangle \mathrm{ml} \rrbracket\end{array}$ & $\begin{array}{l}\text { Recovery } \\
\text { rate \% }\end{array}$ & & & & & & & & & & \\
\hline $\begin{array}{l}\text { 4-tert-butyl } \\
\text { phenol }\end{array}$ & $\begin{array}{l}\text { 4-n-butyl } \\
\text { phenol }\end{array}$ & $\begin{array}{l}4-n- \\
\text { pentyl } \\
\text { phenol }\end{array}$ & $\begin{array}{l}\text { 4-n- } \\
\text { hexyl } \\
\text { phenol }\end{array}$ & $\begin{array}{l}\text { 4-tert- } \\
\text { octyl } \\
\text { phenol }\end{array}$ & $\begin{array}{l}\text { 4-n- } \\
\text { heptyl } \\
\text { phenol }\end{array}$ & $\begin{array}{l}\text { 4- } \\
\text { nonylphenol }\end{array}$ & $\begin{array}{l}\text { 4-n- } \\
\text { octyl } \\
\text { phenol }\end{array}$ & $\begin{array}{l}\text { 4-n- } \\
\text { nonylphenol }\end{array}$ & $\begin{array}{l}\text { bisphenol } \\
\text { A }\end{array}$ & Surrogate & \\
\hline 20 & 95.2 & 99.7 & 111 & 97.0 & 104 & 116 & 95.2 & 96.7 & 99.0 & 98.4 & 100 \\
\hline 30 & 104 & 109 & 116 & 100 & 104 & 118 & 95.2 & 96.3 & 97.6 & 101 & 103 \\
\hline 40 & 107 & 111 & 118 & 101 & 103 & 117 & 98.3 & 97.9 & 97.1 & 103 & 104 \\
\hline 50 & 108 & 113 & 121 & 104 & 106 & 122 & 100 & 101 & 103 & 104 & 104 \\
\hline
\end{tabular}

\subsection{Influence of salt content}

Phenols are water-soluble and need salting out to improve extraction efficiency. The effect of different salt amount on the recovery rate of target substance is shown in Table 7. It can be seen from the table that adding sodium chloride can indeed improve the recovery rate of the target substance, but the improvement effect is not significant. The main reason is that the recovery rate data is high enough without adding salt. After comprehensive consideration, $5 \mathrm{~g}$ sodium chloride can be added in water sample extraction.

Table 7 Average extraction efficiency of C4-C9 alkylphenols and bisphenol A for different salt content

\begin{tabular}{|llllll|}
\hline NaCl Dosage (g) & 0 & 5 & 10 & 20 & 30 \\
\hline 4-tert-butyl phenol & 97.5 & 100 & 103 & 103 & 102 \\
\hline 4-n-butyl phenol & 97.3 & 102 & 103 & 106 & 107 \\
\hline 4-n-pentyl phenol & 107 & 110 & 112 & 115 & 114 \\
\hline 4-n-hexyl phenol & 100 & 106 & 108 & 111 & 112 \\
\hline 4-tert-octyl phenol & 107 & 110 & 110 & 114 & 110 \\
\hline 4-n-heptyl phenol & 102 & 110 & 112 & 115 & 115 \\
\hline 4-nonylphenol & 93.9 & 104 & 103 & 105 & 105 \\
\hline 4-n-octyl phenol & 95.6 & 103 & 109 & 107 & 108 \\
\hline 4-n-nonylphenol & 99.1 & 107 & 113 & 112 & 111 \\
\hline bisphenol A & 107 & 108 & 115 & 110 & 114 \\
\hline Surrogate & 97.8 & 101 & 106 & 109 & 108 \\
\hline
\end{tabular}

\subsection{Effect of drying time during concentration process}

In the standard of organic matter determination in water, when liquid-liquid extraction is used, it is related to whether the extraction liquid is dried during the concentration process. For C4-C9 alkylphenols, some of the target compounds are liquid with vapor pressure, and volatilization occurs when the vacuum is appropriate. Some of the solid targets are powder or velvet with low density, and they also have drift loss when the vacuum is appropriate. The influence of organic phase concentration to $0.5 \mathrm{ml}$ or concentration to dryness and continuous rotary evaporation for different time on the recovery of target substance is shown in Table 8. It can be seen from the table that drying can significantly reduce the detection results, especially for some alkylphenols (4-tert-butylphenyl, etc.) which are liquid at room temperature. The experimental results are consistent with the above analysis. Finally, in the process of concentration, the treatment mode without drying was selected.

Table 8 Average extraction efficiency of C4-C9 alkylphenols and bisphenol A for different drying process 


\begin{tabular}{|c|c|c|c|c|}
\hline Drying time $₫ \min \rrbracket$ & Condense to $0.5 \mathrm{ml}$ & 1 & 5 & 10 \\
\hline 4-tert-butyl phenol & 102 & 40.1 & 21.5 & 20.9 \\
\hline 4-n-butyl phenol & 100 & 54.0 & 22.3 & 18.8 \\
\hline 4-n-pentyl phenol & 104 & 73.2 & 32.3 & 23.2 \\
\hline 4-n-hexyl phenol & 102 & 84.6 & 56.1 & 44.4 \\
\hline 4-tert-octyl phenol & 103 & 88.1 & 60.7 & 53.7 \\
\hline 4-n-heptyl phenol & 104 & 90.9 & 79.4 & 74.4 \\
\hline 4-nonylphenol & 100 & 92.3 & 82.5 & 74.9 \\
\hline 4-n-octyl phenol & 99.6 & 90.5 & 87.8 & 84.7 \\
\hline 4-n-nonylphenol & 104 & 95.4 & 94.1 & 92.6 \\
\hline bisphenol A & 102 & 93.6 & 94.6 & 92.1 \\
\hline Surrogate & 101 & 95.1 & 96.0 & 92.9 \\
\hline
\end{tabular}

\subsection{Spectrogram}

The chromatogram of the standard sample of the target analytes is shown in Fig 1. It can be seen from the figure that under the conditions of reference gas chromatography-mass spectrometry, the peaks of each compound are independent and clear. Due to the use of derivatization treatment, there is basically no tailing phenomenon of phenolic compounds. 4-nonylphenol is a mixed peak of one group of isomers, and other compounds are single peaks.

\subsection{Standard curve}

The linear correlation coefficient of the standard curve of the object to be measured is shown in Table 9 . It can be seen from the table that the standard curves of the target compounds are linear.

Table 9 Linear correlation coefficient, detection limit and lower limit of determination of C4-C9 alkylphenols and bisphenol A

\begin{tabular}{|c|c|c|c|c|c|c|c|c|c|c|}
\hline RSD of RRF & $\begin{array}{l}\text { 4-tert- } \\
\text { butyl } \\
\text { phenol }\end{array}$ & $\begin{array}{l}\text { 4-n- } \\
\text { butyl } \\
\text { phenol }\end{array}$ & $\begin{array}{l}\text { 4-n- } \\
\text { pentyl } \\
\text { phenol }\end{array}$ & $\begin{array}{l}\text { 4-n- } \\
\text { hexyl } \\
\text { phenol }\end{array}$ & $\begin{array}{l}\text { 4-tert- } \\
\text { octyl } \\
\text { phenol }\end{array}$ & $\begin{array}{l}\text { 4-n- } \\
\text { heptyl } \\
\text { phenol }\end{array}$ & $\begin{array}{l}\text { 4- } \\
\text { nonylphenol }\end{array}$ & $\begin{array}{l}\text { 4-n- } \\
\text { octyl } \\
\text { phenol }\end{array}$ & $\begin{array}{l}\text { 4-n- } \\
\text { nonylphenol }\end{array}$ & $\begin{array}{l}\text { bisphenol } \\
\text { A }\end{array}$ \\
\hline $\begin{array}{l}\text { Low concentration } \\
\text { curve }\end{array}$ & $12.2 \%$ & $6.02 \%$ & $6.21 \%$ & $6.30 \%$ & $5.85 \%$ & $6.71 \%$ & $8.00 \%$ & $4.04 \%$ & $4.31 \%$ & $3.05 \%$ \\
\hline $\begin{array}{l}\text { High concentration } \\
\text { curve }\end{array}$ & $1.71 \%$ & $3.42 \%$ & $4.87 \%$ & $7.03 \%$ & $5.36 \%$ & $10.7 \%$ & $3.18 \%$ & $9.64 \%$ & $9.64 \%$ & $6.47 \%$ \\
\hline detection limit $(\mu \mathrm{g} / \mathrm{L})$ & 0.002 & 0.002 & 0.002 & 0.002 & 0.002 & 0.002 & 0.006 & 0.002 & 0.003 & 0.003 \\
\hline $\begin{array}{l}\text { Lower limit of } \\
\text { determination }(\mu \mathrm{g} / \mathrm{L})\end{array}$ & 0.008 & 0.008 & 0.008 & 0.008 & 0.008 & 0.008 & 0.024 & 0.008 & 0.012 & 0.012 \\
\hline
\end{tabular}

\subsection{Method detection limit}

The detection limit of the method was confirmed according to the relevant environmental protection standard method (HJ 168 2020), and seven laboratory blank samples with or without the target objects working solution were analyzed continuously. Because 4-tert-butylphenyl, 4-tert-octylphenyl, 4nonylphenol and bisphenol A were detected in the laboratory blank, the detection limits of these target substances were determined by the method of laboratory blank without standard addition and the detection limits of the remaining analytes were determined by the method of laboratory blank with standard addition. The concentration of these remaining analytes in the laboratory blank sample with standard addition is all $0.010 \mu \mathrm{g} / \mathrm{L}$. The lower limit of determination is 4 times of the detection limit and both of which are listed in Table 9 . These detection limits of the target compounds changes from $0.002 \mu \mathrm{g} / \mathrm{L}$ to $0.006 \mu \mathrm{g} / \mathrm{L}$ and the lower limit of determination from $0.008 \mu \mathrm{g} / \mathrm{L}$ to $0.024 \mu \mathrm{g} / \mathrm{L}$.

\subsection{Recovery and precision}

Taking the laboratory water without the target analytes as the blank matrix, C4-C9 alkylphenols and bisphenol A standard solutions with three different concentration levels were added respectively. The pretreatment and test were carried out according to the method steps. Each concentration level was determined for six times in parallel. The relative standard deviation results are shown in table 10. Take surface water, sewage and wastewater as sample matrix, add C4-C9 alkylphenols and bisphenol A standard solution with matrix concentration level of 0.5-3 times, repeat the above laboratory test, and the average recovery results are shown in Table 11 . The relative standard deviations of the target samples ranged from $0.67 \%$ to $13.7 \%$, and the average recovery ranged from $68.0 \%$ to $122 \%$, which indicates that the precision and accuracy of the experiment are good. 


\begin{tabular}{|c|c|c|c|c|c|c|c|c|c|c|}
\hline $\begin{array}{l}\text { Spiked } \\
\text { concentration } \\
(\mu \mathrm{g} / \mathrm{L})\end{array}$ & $\begin{array}{l}\text { Relative } \\
\text { standard } \\
\text { deviation\% }\end{array}$ & & & & & & & & & \\
\hline $\begin{array}{l}\text { 4-tert-butyl } \\
\text { phenol }\end{array}$ & 4-n-butyl phenol & $\begin{array}{l}\text { 4-n- } \\
\text { pentyl } \\
\text { phenol }\end{array}$ & $\begin{array}{l}\text { 4-n-hexyl } \\
\text { phenol }\end{array}$ & $\begin{array}{l}\text { 4-tert- } \\
\text { octyl } \\
\text { phenol }\end{array}$ & $\begin{array}{l}\text { 4-n- } \\
\text { heptyl } \\
\text { phenol }\end{array}$ & $\begin{array}{l}\text { 4- } \\
\text { nonylphenol }\end{array}$ & $\begin{array}{l}\text { 4-n- } \\
\text { octyl } \\
\text { phenol }\end{array}$ & $\begin{array}{l}\text { 4-n- } \\
\text { nonylphenol }\end{array}$ & $\begin{array}{l}\text { bisphenol } \\
\text { A }\end{array}$ & \\
\hline 0.02 & 9.52 & 4.62 & 3.93 & 2.90 & 2.68 & 4.69 & 10.1 & 10.2 & 12.3 & 7.08 \\
\hline 0.50 & 3.20 & 2.15 & 1.88 & 1.92 & 1.96 & 1.79 & 2.49 & 2.29 & 3.12 & 2.44 \\
\hline 2.0 & 2.05 & 2.42 & 2.12 & 2.19 & 1.51 & 1.74 & 5.32 & 7.20 & 13.7 & 0.67 \\
\hline
\end{tabular}

Table 11 Recovery datas

\begin{tabular}{|c|c|c|c|c|c|c|c|c|c|c|c|}
\hline $\begin{array}{l}\text { Water } \\
\text { sample }\end{array}$ & $\begin{array}{l}\text { Spiked } \\
\text { concentration }(\mu \mathrm{g} / \mathrm{L})\end{array}$ & $\begin{array}{l}\text { Recovery } \\
\text { rate of } \\
\text { standard } \\
\text { addition } \\
\%\end{array}$ & & & & & & & & & \\
\hline $\begin{array}{l}\text { 4-tert-butyl } \\
\text { phenol }\end{array}$ & 4-n-butyl phenol & $\begin{array}{l}\text { 4-n- } \\
\text { pentyl } \\
\text { phenol }\end{array}$ & $\begin{array}{l}\text { 4-n- } \\
\text { hexyl } \\
\text { phenol }\end{array}$ & $\begin{array}{l}\text { 4-tert- } \\
\text { octyl } \\
\text { phenol }\end{array}$ & $\begin{array}{l}\text { 4-n- } \\
\text { heptyl } \\
\text { phenol }\end{array}$ & $\begin{array}{l}\text { 4- } \\
\text { nonylphenol }\end{array}$ & $\begin{array}{l}\text { 4-n- } \\
\text { octyl } \\
\text { phenol }\end{array}$ & $\begin{array}{l}\text { 4-n- } \\
\text { nonylphenol }\end{array}$ & $\begin{array}{l}\text { bisphenol } \\
\text { A }\end{array}$ & & \\
\hline Sewage & 0.05 & 106 & 96.0 & 111 & 104 & 102 & 101 & 90.7 & 112 & 99.1 & 107 \\
\hline $\begin{array}{l}\text { Surface } \\
\text { water }\end{array}$ & 0.50 & 99.5 & 102 & 110 & 116 & 121 & 122 & 72.4 & 79.1 & 88.2 & 68.0 \\
\hline Wastewater & 2.0 & 95.9 & 102 & 104 & 107 & 104 & 111 & 97.9 & 102 & 98.6 & 91.4 \\
\hline
\end{tabular}

\subsection{Determination of typical representative water samples}

The contents of target analytes in groundwater, surface water, sewage, wastewater and seawater samples are shown in Table 12. It can be seen from the table that the contents of 4-nonylphenol and bisphenol $\mathrm{A}$ in the environmental water in Dongying City are below the requirements of relevant directives at home and abroad (GB 31572 2015; GB 31571 2015; U.S. EPA 2005; European Commission EC 2003), and the contents of target substances in groundwater, surface water and seawater are very low.

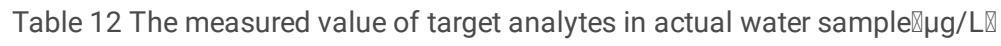




\begin{tabular}{|c|c|c|c|c|c|c|c|c|c|c|c|}
\hline $\begin{array}{l}\text { 4-tert-butyl } \\
\text { phenol }\end{array}$ & $\begin{array}{l}4-n- \\
\text { butyl } \\
\text { phenol }\end{array}$ & $\begin{array}{l}\text { 4-n- } \\
\text { pentyl } \\
\text { phenol }\end{array}$ & $\begin{array}{l}\text { 4-n- } \\
\text { hexyl } \\
\text { phenol }\end{array}$ & $\begin{array}{l}\text { 4-tert- } \\
\text { octyl } \\
\text { phenol }\end{array}$ & $\begin{array}{l}\text { 4-n- } \\
\text { heptyl } \\
\text { phenol }\end{array}$ & $\begin{array}{l}\text { 4- } \\
\text { nonylphenol }\end{array}$ & $\begin{array}{l}\text { 4-n- } \\
\text { octyl } \\
\text { phenol }\end{array}$ & $\begin{array}{l}\text { 4-n- } \\
\text { nonylphenol }\end{array}$ & $\begin{array}{l}\text { bisphenol } \\
\text { A }\end{array}$ & $\begin{array}{l}\text { Surrogate } \\
\text { Recovery }\end{array}$ & \\
\hline Groundwater & n.d. & n.d. & n.d. & n.d. & n.d. & n.d. & n.d. & n.d. & n.d. & 0.016 & $124 \%$ \\
\hline $\begin{array}{l}\text { Surface } \\
\text { water } 1\end{array}$ & n.d. & n.d. & n.d. & n.d. & 0.003 & n.d. & 0.049 & n.d. & n.d. & 0.023 & $125 \%$ \\
\hline $\begin{array}{l}\text { Surface } \\
\text { water } 2\end{array}$ & n.d. & n.d. & n.d. & n.d. & n.d. & n.d. & 0.026 & n.d. & n.d. & 0.032 & $78.6 \%$ \\
\hline $\begin{array}{l}\text { Surface } \\
\text { water } 3\end{array}$ & 0.031 & 0.007 & n.d. & n.d. & 0.008 & 0.002 & 0.139 & 0.002 & 0.003 & 0.068 & $92.3 \%$ \\
\hline $\begin{array}{l}\text { Surface } \\
\text { water } 4\end{array}$ & n.d. & n.d. & n.d. & n.d. & n.d. & n.d. & 0.228 & n.d. & n.d. & 0.226 & $77.4 \%$ \\
\hline Sewage 1 & 0.004 & 0.008 & n.d. & n.d. & 0.019 & 0.003 & 0.965 & 0.003 & n.d. & 0.024 & $110 \%$ \\
\hline Sewage 2 & n.d. & n.d. & n.d. & n.d. & n.d. & n.d. & 0.344 & n.d. & n.d. & 0.156 & $88.5 \%$ \\
\hline $\begin{array}{l}\text { Wastewater } \\
1\end{array}$ & 0.002 & n.d. & n.d. & n.d. & 0.007 & n.d. & 1.37 & n.d. & 0.001 & 0.200 & $115 \%$ \\
\hline $\begin{array}{l}\text { Wastewater } \\
2\end{array}$ & n.d. & n.d. & n.d. & n.d. & n.d. & n.d. & 0.207 & n.d. & n.d. & 0.029 & $81.9 \%$ \\
\hline $\begin{array}{l}\text { Wastewater } \\
3\end{array}$ & n.d. & n.d. & n.d. & n.d. & n.d. & n.d. & 1.81 & n.d. & n.d. & 2.30 & $70.5 \%$ \\
\hline $\begin{array}{l}\text { Wastewater } \\
4\end{array}$ & 0.006 & 0.004 & 0.005 & 0.007 & 0.016 & 0.017 & 0.218 & 0.064 & 0.094 & 0.870 & $97.9 \%$ \\
\hline $\begin{array}{l}\text { Wastewater } \\
5\end{array}$ & 0.004 & n.d. & n.d. & n.d. & 0.009 & n.d. & 0.114 & 0.026 & 0.035 & 32.8 & $87.3 \%$ \\
\hline Seawater & n.d. & 0.003 & 0.001 & n.d. & n.d. & 0.002 & 0.077 & 0.008 & n.d. & 0.011 & $104 \%$ \\
\hline
\end{tabular}

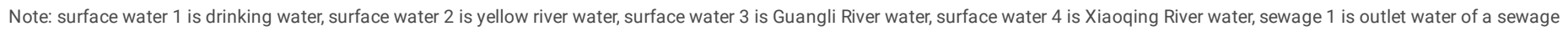

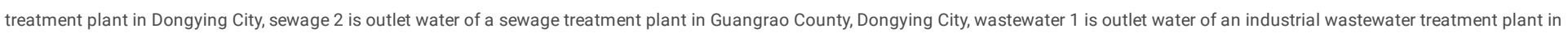

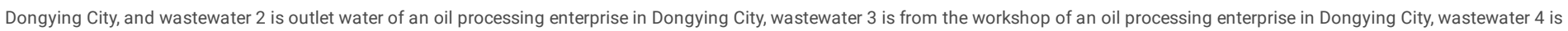
from the workshop of a bisphenol A production enterprise in Dongying City, and wastewater 5 is from the workshop of a bisphenol A production enterprise in Dongying City.

\section{Conclusions}

(1) Aiming to monitor of C4-C9 alkylphenols and bisphenol A in water, A liquid-liquid extraction combined with derivatization and gas chromatographymass spectrometry (GC-MS) method was used to optimize the extraction solvent, extraction times, extraction time, extraction solvent volume, acidity, salt content, rotary distillation concentration degree and other conditions. After optimization, dichloromethane was used as the extraction solvent, the extraction time was $5 \mathrm{~min}$, the extraction solvent was $30 \mathrm{ml}$, the $\mathrm{pH}$ value was less than 2, and the amount of salt was $5 \mathrm{~g}$.

(2) The method has the advantages of high sensitivity, low detection limit, accurate quantification and good precision, which can meet the needs of the determination of C4-C9 alkylphenols and bisphenol A in water.

(3) The method was used to detect the groundwater, surface water, sewage, wastewater and sea water samples in Dongying City located at the Yellow River Estuary. The results showed that the contents of 4-nonylphenol and bisphenol A in the samples were lower than the requirements of relevant directives at home and abroad.

\section{Declarations}

Acknowledgments We appreciate the help of the Ecological and Environmental Monitoring Center of Dongying Municipal of Shandong Province in sample testing.

Authors' contributions Ziqi Guo, Xinliang Liu and Jian Zhao carried out the experiment. Hailiang Yin and Tongna Zhou put forward the idea. All authors have read and approved the final manuscript.

Funding information This work was supported by Standard Development and Revision Project of Ministry of Ecological Environment of China (Grant Nos. 2014-31), Shandong Provincial Natural Science Foundation, Chian囚ZR2019MB022囚and the Fundamental Research Funds for the Central Universities (19CX02063A).

Availability of data and materials Not applicable. 
Ethics approval and consent to participate Not applicable.

Consent for publication Not applicable.

Competing interests The authors declare that they have no competing interests.

\section{References}

Abu-Alsoud GF, Bottaro CS (2021) Porous thin-film molecularly imprinted polymer device for simultaneous determination of phenol, alkylphenol and chlorophenol compounds in water. Talanta 223:121727

ASTM D7065 (2011) Standard Test Method for Determination of Nonylphenol, Bisphenol A, p-tert- Octylphenol, Nonylphenol Monoethoxylate and. Nonylphenol Diethoxylate in Environmental Waters by Gas Chromatography Mass Spectrometry.

ASTM D7574 (2009) Standard Test Method for Determination of Bisphenol A in Environmental Waters by Liquid Chromatography/Tandem Mass Spectrometry.

Azzouz A, Colón LP, Hejji L, Ballesteros E (2020) Determination of alkylphenols, phenylphenols, bisphenol A, parabens, organophosphorus pesticides and triclosan in different cereal-based foodstuffs by gas chromatography-mass spectrometry. Anal Bioanal Chem 412:2621-2631

Deng HL, Su XJ, Wang HB (2018) Simultaneous Determination of Aflatoxin B1, Bisphenol A, and 4-Nonylphenol in Peanut Oils by Liquid-Liquid Extraction Combined with Solid-Phase Extraction and Ultra-High Performance Liquid Chromatography-Tandem Mass Spectrometry. Food Anal Method 11:13031311

Dong CD, Chen CW, Chen CF (2015) Seasonal and spatial distribution of 4-nonylphenol and 4-tert-octylphenol in the sediment of Kaohsiung Harbor, Taiwan. Chemosphere 134:588-597

European Commission EC (2003) Directive 2000/60/EC of the European Parliament and of the Council of 23 October 2000 establishing a framework for Community action in the field of water policy, Official journal of the european communities, OJ L 327, 22.12.2000, pp 1-73

GB 31572 (2015) Emission standard of pollutants for synthetic resin industry. Beijing.

GB 31571 (2015) Emission standard of pollutants for petroleum chemistry industry. Beijing.

HJ 168 (2020) Technical guideline for the development of environmental monitoring analytical method standards. Beijing.

HJ 91.1 (2019) Technical specifications for wastewater monitoring. Beijing.

HJ/T 164 (2020) Technical specifications for environmental monitoring of groundwater. Beijing.

HJ/T 493 (2009) Water quality sampling - technical regulation of the preservation and handling of samples. Beijing.

ISO 18857-2 (2009) Water quality-Determination of selected alkylphenols-Part 2: Gas chromatographic-mass spectrometric determination of alkylphenols, their ethoxylates and bisphenol A in non-filtered samples following solid-phase extraction and derivatisation.

JIS K 0450-10-10 (2006) Testing method for bisphenol A in industrial water and waste water.

Liu LY, Zhao Q (2020) A simple fluorescence anisotropy assay for detection of bisphenol A using fluorescently labeled aptamer. J Environ Sci 32(11):1924

Liu ZR, Li YY, Sun LW, Yang H, Zheng X, Wang LB (2019) Investigation of diazo-derivatization of bisphenol A and its applicability for quantitation in food safety inspections using high-performance liquid chromatography. Biomedical Chromatography 33:e4419

Martinez M, Peñuela GA (2013) Analysis of triclosan and 4-n-nonylphenol in Colombian reservoir water by gas chromatography-mass spectrometry. Water Environ J 27:387-395

Ministry of the Environment of Japan (1998) Environment Agency's Basic Policy on Environmental Endocrine Disruptors, Strategic Programs on Environmental Endocrine Disruptors SPEED'98. Tokyo.

Murray A, Örmeci B, Lai EPC (2017) Use of sub-micron sized resin particles for removal of endocrine disrupting compounds and pharmaceuticals from water and wastewater. J Environ Sci 29(1):256-264.

Santhi VA, Hairin T, Mustafa AM (2012) Simultaneous determination of organochlorine pesticides and bisphenol A in edible marine biota by GC-MS. Chemosphere 86(10):1066-1071

Page 10/11 
Selvaraj KK, Shanmugam G, Sampath S, Larsson DGJ, Ramaswamy BR (2014) GC-MS determination of bisphenol A and alkylphenol ethoxylates in river water from India and their ecotoxicological risk assessment. Ecotox Environ Safe 99:13-20

Shen G, Yu G, Cai ZX, Zhang ZL (2005) Development of an analytical method to determine phenolic endocrine disrupting chemicals in sewage and sludge by GC/MS. Chinese Sci Bull 50:2681-2687

Subuhi NEAM, Saad SM, Zain NNM, Lim V, Miskam M, Kamaruzaman S, Raoov M, Yahaya N (2020) An efficient biosorption-based dispersive liquid-liquid microextraction with extractant removal by magnetic nanoparticles for quantification of bisphenol A in water samples by gas chromatography-mass spectrometry detection. J Sep Sci 43(16):3294-3303

U.S. EPA (2005) Aquatic Life Ambient Water Quality Criteria Nonylphenol FINAL, Washington DC, EPA-822-R-05-005.

Wang DX, Wang XC, Hu QJ, Zhang CX, Li F (2020) Salting-Out Assisted Liquid-Liquid Extraction Coupled to Dispersive Liquid-Liquid Microextraction for the Determination of Bisphenol A and Six Analogs (B, E, F, S, BADGE, BFDGE) in Canned Coffee Drinks by Ultra-Performance Liquid ChromatographyTandem Mass Spectrometry. Food Anal Method https://doi.org/10.1007/S12161-020-01879-0

Wang SY, Liu F, Liu YL, Chen L (2013) Determination of 12 Isomers of p-Nonylphenol in Groundwater by Gas Chromatography-Mass Spectrometry. Chinese J Anal Chem 43(11):1699-1703

Wen HJ, Chang TC, Ding WH, Tsai SF, Hsiung CA, Wang S L (2020) Exposure to endocrine disruptor alkylphenols and the occurrence of endometrial cancer. Environ Pollut 267:115475

Tan DQ, Jin J, Wang LX, He XL, Guo CC, Lu XB, Chen JP (2019) Quantification of bisphenol A and its selected analogs in serum using pre-column derivatization with high-performance liquid chromatography and tandem mass spectrometry. J Sep Sci 42(5):991-998

\section{Figures}

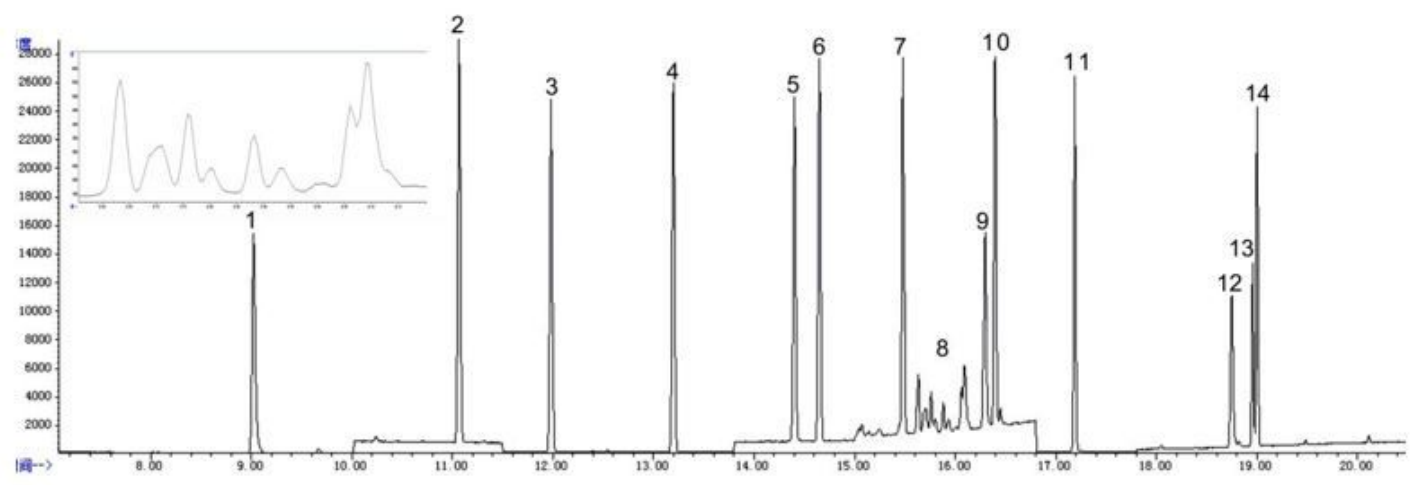

\section{Figure 1}

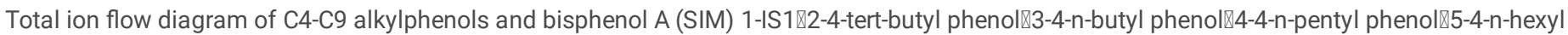

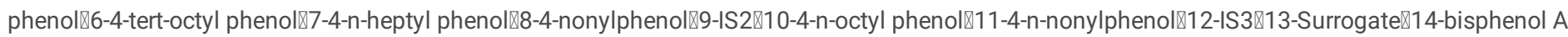

\section{Supplementary Files}

This is a list of supplementary files associated with this preprint. Click to download.

- GraphicalAbstract.docx 